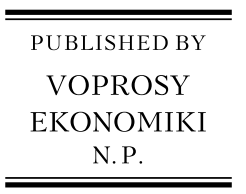

\title{
Factors determining intra-regional fiscal decentralization in Russia and the US
}

\author{
Michael Alexeeva,b,*, Arseny Mamedov ${ }^{\mathrm{b}, \mathrm{c}}$ \\ a Indiana University, Bloomington, Indiana, USA \\ ${ }^{b}$ Russian Academy of National Economy and Public Administration, Moscow, Russia \\ ${ }^{c}$ Gaidar Institute for Economic Policy, Moscow, Russia
}

\begin{abstract}
We use panel data for Russia's regions (2005-2013) and the US states (1997-2013) and several different econometric specifications to estimate and compare the determinants of fiscal decentralization in the two countries. We find that while the factors of decentralization in the US states largely conform to existing theoretical predictions, this is not so for Russia, where almost no factors are consistently associated with intraregional fiscal decentralization. Moreover, our results for Russia differ from prior results based on earlier data. We conjecture that the recent weakening of the effects of conventional fiscal decentralization determinants in Russia is due to the decline of democratic institutions in Russia's regions and overall political and economic centralization in the country.

(C) 2017 Non-profit partnership "Voprosy Ekonomiki”. Hosting by Elsevier B.V. All rights reserved.
\end{abstract}

JEL classification: $\mathrm{H} 72, \mathrm{H} 77, \mathrm{P} 51$.

Keywords: fiscal federalism, expenditure decentralization, Russian economy, US economy.

\section{Introduction}

The effects of fiscal decentralization have been the subject of fast growing literature in economics and political science. ${ }^{1}$ This literature typically treats fiscal decentralization as exogenous. This approach could lead to misleading results if the factors that determine the degree of fiscal decentralization also affect its presumed effects, such as institutional quality or economic growth. For this reason, it is important to understand what factors determine the degree of fiscal decentrali-

\footnotetext{
* Corresponding author, E-mail address: malexeev@indiana.edu

Peer review under responsibility of Voprosy Ekonomiki.

1 See Martinez-Vazquez et al. (2016) for a recent survey of the economic and political effects of fiscal decentralization. Another useful recent reference is Ahmad and Brosio (2015).
} 
zation. Unfortunately, there has been little recent research on this topic. In fact, we are aware of only four papers on the determinants of fiscal decentralization published in the last 12 years (Canavire-Bacarreza et al., 2016; Freinkman and Plekhanov, 2009; Letelier, 2005; Arzaghi and Henderson, 2005). ${ }^{2}$ More research on this issue was conducted in the 1980s and 1990s, but much of it used arguably inadequate empirical techniques.

Perhaps more important for our purposes, the overwhelming majority of the empirical work on the determinants of fiscal decentralization both recently and in the 1980s-1990s used country-level data. Two notable exceptions are Wallis and Oates (1988; herafter W\&O) and Freinkman and Plekhanov (2009; hereafter F\&P) who studied the determinants of fiscal decentralization in the US states and Russian regions, respectively. Although there are certain advantages of working at the country level due to generally better data availability, there are also significant disadvantages. First, countries generally differ in difficult to measure ways, which cannot always be accounted for using country fixed effects because some of these differences vary over time. Second, budgetary accounting systems and general government responsibilities may vary from one country to another in ways that undermine the validity of comparing decentralization measures across countries. Third, countries' reporting of budgetary data to international organizations, whose data are typically used in country-level research, is sometimes inconsistent. For example, there are non-trivial discrepancies between the World Bank and OECD data on the subnational government share of expenditures. ${ }^{3}$

All of these problems can be alleviated or even eliminated by studying the determinants of fiscal decentralization at the intraregional level, that is, looking at the fiscal arrangements between provincial (regional in Russia and state in the US) and municipal government levels. This is the focus of our paper. More specifically, we aim to extend and improve upon W\&O and F\&P's work on the factors of regional fiscal decentralization by employing more sophisticated and, in our view, more appropriate econometric approaches as well as more recent and comprehensive data.

In terms of econometric techniques, W\&O used a random effects specification in their main regressions. However, the Hausman test rejects random effects for our data. F\&P present only between-effects results, arguing that a fixed effects specification would not work because, "most indicators do not have meaningful time-series variation within short periods of time" (Freinkman and Plekhanov, 2009, p. 508) and because they focus on long-term trends. Although we agree that a between-effects specification is a useful technique for the problem at hand (and we present betweeneffects results), it also has significant disadvantages relative to fixed effects approaches. In particular, a between-effects estimation is likely to suffer from an omit-

\footnotetext{
2 Jametti and Joanis (2016) also addressed the determinants of fiscal decentralization, but they focused almost exclusively on electoral competition and other political variables without including several other potentially important factors common in this literature, such as a measure of ethnic diversity within the population or dependence on natural resource rents.

3 According to the World Bank's data, the shares of subnational government expenditures in general government expenditures in Belgium, Finland, France, and Greece in 2011 were, respectively, 33.06\%, 35.02\%, $18.67 \%$, and $5.53 \%$. Meanwhile, the respective numbers from the OECD database are $37.75 \%, 40.73 \%, 20.02 \%$, and $5.58 \%$. Moreover, the differences do not remain stable over time. Thus, the World Bank reports a $5.10 \%$ share for Greece for 2010 while the OECD number is 7.16\%. These numbers are taken from World Bank (2014) and OECD (2017).
} 
ted variable problem. Additionally, our data has sufficient variation over time among relevant time-varying variables, so that we can obtain fairly reliable estimates even in fixed-effects specifications. The difference might be due to our somewhat longer sample period (nine years vs. six years in F\&P for Russia and 15 years for the US).

Unlike W\&O and F\&P, we use both between-effects and three different specifications that account for regional fixed effects. In addition to the conventional OLS fixed effects (OLS FE), we also use system-GMM dynamic panel estimation approach and spatial lags dynamic panel regressions with fixed effects. The system-GMM technique can, in principle, account for potential endogeneities and for serial correlation in the error terms. However, a system-GMM is not highly reliable when cross-sectional dimension is relatively small, as is the case in our data, especially for the US states. The spatial lags specification is particularly appropriate for working with regional data because capital and labor as well as information about institutional arrangements and performance travel much easier between regions within the same country than between countries.

Using more recent data is most important for the Russian case, where rather radical changes in intergovernmental budgetary and other relations took place after 1996-2001, which was the focus of F\&P's study. For example, popular elections of regional governments were abolished in late 2004. Our data covers the period in which the President appointed regional governors (governor elections resumed under new rules in late 2012). In addition, since 2000, both revenues and expenditures have been increasingly concentrated at the federal level. The entire system of intergovernmental budgetary transfers has also changed significantly since the early 2000s. Intraregional budgeting and management in particular were reformed starting in 2005, with 2006-2008 serving as a transition period.

For the US, the main data-related advantage our work has over W\&O relates to better data availability. For example, we have and use data on income inequality within the states, state dependence on federal transfers, and the share of social welfare transfers in state expenditures, all of which turn out to be significant determinants of intrastate fiscal decentralization.

The rest of the paper proceeds as follows. The next section outlines the expected effects of the main determinants of fiscal decentralization. Section 3 describes the data we use in our regressions. Econometric specifications are presented in Section 4. Section 5 reports the estimation results and discusses their implications. Section 6 provides the concluding remarks.

\section{Theoretical determinants of fiscal decentralization}

Theoretical work on the factors of fiscal decentralization suggests that countries or regions would be more decentralized if their populations are more diverse along various dimensions, if the relevant public goods can be provided reasonably efficiently at a lower level of government, and if lower government levels have access to adequate revenue sources. It is important to state, however, that these theoretical considerations depend on the country's political system to some extent, and particularly on the degree of government accountability to citizens at all levels. Below, we briefly discuss how the factors included in our regressions are expected to affect fiscal decentralization. We present only the main theoretical considerations, omitting some of the less important arguments. This discussion 
is based mainly on W\&O, Panizza (1999), Letelier (2005), and F\&P. Note that we will refer to "regions," although the same arguments also apply to countries.

\subsection{Region size}

Regional size reflected either in land area or in population is expected to result in greater fiscal decentralization. This is because larger regions would typically be more diverse in terms of the population's preferences and because lower-level entities in more populous regions could still have an adequate size to produce local public goods relatively efficiently. In addition, larger regions, particularly those that have large land areas, are difficult to administer from a single center, although this depends in part on the degree of development of relevant transportation and communications networks.

\subsection{Ethnic or racial diversity}

Ethnic or racial diversity usually implies a diversity of tastes that is easier to accommodate in a fiscally decentralized entity. However, if the main ethnic group does not constitute a large majority of the population, it may be less willing to allow decentralization in order to exert greater political and fiscal control over smaller groups. Therefore, the relationship between ethnic/racial diversity and fiscal decentralization is ambiguous.

\subsection{Degree of urbanization}

A higher share of urban population makes it possible to provide public goods relatively cheaply in a decentralized manner. However, the effect of urban share depends on whether it becomes large due to one big city in a region or due to several relatively large urban areas. In the former case, urban population share is expected to be negatively related to decentralization, while in the latter case, we expect the opposite relationship. Therefore, it is difficult to predict the relationship between urbanization and fiscal decentralization without knowing the distribution of the urban population among cities of different sizes. ${ }^{4}$

\subsection{Income inequality}

In theory, income inequality has an ambiguous effect on fiscal decentralization. On the one hand, greater income inequality implies more diversity of tastes and thus promotes decentralization. On the other hand, greater inequality implies the need for redistribution, which is more efficient from the center, thus favoring centralization.

\subsection{Social welfare transfers}

Social welfare transfers are most likely to promote fiscal centralization because it is generally administratively easier to make transfers from a single center.

\footnotetext{
${ }^{4}$ In a well-functioning market economy, city size would typically follow Zipf's law (Gabaix, 1999). However, this regularity might not apply to Russia's regions due to the legacy of central planning.
} 
More important, providing transfers of different sizes in different municipalities creates incentives for transfer recipients to relocate to localities with more generous provisions of transfers.

\subsection{Per-capita output}

The level of economic development measured by per-capita output has an ambiguous effect on fiscal decentralization. Higher average income is typically associated with a greater diversity of preferences, favoring decentralization. Put differently, fiscal decentralization is a normal or even a luxury good (Prud'homme, 1995). In contrast, $\mathrm{W} \& \mathrm{O}$ argue that citizens in richer regions are more likely to dislike high inequality and, therefore, tend to engage in greater redistribution, which favors centralization (see the argument for social welfare transfers above). However, given that we control for social welfare transfers, we expect richer regions to be more fiscally decentralized.

\subsection{Natural resource dependence}

Dependence on natural resources, particularly those that generate large economic rent, is likely to promote fiscal centralization for at least two reasons. First, rents from natural resources are typically collected at the regional center rather than in municipalities, generating what is known as the "flypaper effect," according to which windfall revenues and rents are spent mainly by the government level that receives them. ${ }^{5}$ The other reason to expect natural resource dependence to favor fiscal centralization is that a government with access to natural resource rents is less accountable to its citizens and less dependent on the potentially beneficial incentives that fiscal decentralization would engender for municipalities (F\&P).

\subsection{Regional dependence on transfers}

The impact of a region's dependence on transfers from a federal government is similar to that of natural resource rents. Here, we also have both the flypaper effect (transfers from the federal center flow mostly to the regional government rather than directly to municipalities) and a lower dependence of regional government on municipal incentives. In effect, both natural resource revenues and transfers from the federal government can be viewed as rents accruing mainly to the regional government.

\section{Data}

We first describe the basic nature of our dependent and independent variables and then address the specifics of calculating these variables for each country. Our dependent variables reflect expenditure decentralization within the regions. Some authors (e.g., W\&O and Letelier, 2005) also estimate the determinants of revenue decentralization. We view expenditure decentralization as a preferred measure of

\footnotetext{
5 Although there were some attempts to argue that this effect results from some data or econometric problems, Inman (2008) shows that it is "an outcome of political institutions and the associated incentives of elected officials." We also note that in Russia, during our sample period, taxes imposed on oil and natural gas extraction accrued almost completely to the federal government. However, taxes on mining company profits and taxes on wages of the miners accrue overwhelmingly to the regional governments.
} 
decentralization because the theoretical arguments about the determinants of decentralization are usually based on the level of government that is best positioned for particular types and amounts of spending. Additionally, we think that expenditure decentralization better reflects the true degree of fiscal decentralization within a region because in the short term, regions generally have less control over revenue allocation between different government levels than they do over the allocation of expenditures. Transfers can change the latter, while tax legislation and the tax capacity of different levels of government mainly determine the former. For example, in the US, severance taxes generally accrue to the state government rather than to municipalities, implying that mining would necessarily be associated with greater revenue centralization, even though this would be due to the nature of mineral deposits rather than to particular institutional arrangements. Studies of decentralization determinants also much more commonly use expenditure decentralization. ${ }^{6}$

We employ a number of control variables measuring factors that various authors mentioned as potentially important for fiscal decentralization. These relate to the size of the region (logarithms of area and population), its demographic composition (ethnic/racial diversity measured by the share of the majority group and a homogeneity index, and the share of urban population), and socioeconomic measures (logarithms of per-capita regional product and per-capita mining output, the share of welfare transfers in household incomes, Gini index for income inequality, and regional budget dependence on federal ttransfers). In addition, for the US, we use a dummy variable for the individualistic political nature of a state (Elazar, 1966), and for Russia, we include a regional democracy index for 2000-2004 developed by the Moscow Carnegie Center. Except for the individualistic political nature variable, the measures we use are rather typical in studies of the determinants of fiscal decentralization. ${ }^{7}$ Moreover, these or similar variables were used in the earlier work on the determinants of fiscal decentralization in Russia and the US (specifically, F\&P and W\&O). Employing this set of variables makes our estimates comparable between countries and to these earlier studies. We experimented with other demographic variables such as the share of working age population and the share of students, as well as an investment risk index for Russia's regions, but they did not produce consistently significant estimates and did not qualitatively affect our other results.

\subsection{Russia}

The structure of the Russian Federation has been changing over the years. At the end of our sample period (2005-2013) the Federation consisted of 83 "Subjects of the Federation" or regions subdivided into municipalities. Most of the regions are referred to as provinces (oblast), but there are also "republics," other types of provinces (krais), autonomous districts (okrugs), and two federal cities, Moscow and St. Petersburg. Both politically and fiscally, Russia is one of the more centralized federal countries worldwide. The federal tax service collects

\footnotetext{
${ }^{6}$ Of 25 studies of the determinants of fiscal decentralization listed in Table 1 in Letelier (2005), 12 use both expenditure and revenue based measures, while 13 use only expenditure decentralization measures. No study in the table is based exclusively on the revenue decentralization measure.

7 This dummy variable does not significantly affect the other estimates, but we view it as a potentially important exogenous determinant of fiscal decentralization.
} 
all taxes, and then the revenues are channeled into the budgets of the appropriate level of government. Although by law there are federal, regional, and municipal taxes, federal legislation imposes limits on the ability of lower levels of government to alter the base and the rates of "their" taxes. Moreover, almost all revenue from the two important federal taxes (corporate income tax and personal income tax) accrues to regional and municipal budgets by federal law. ${ }^{8}$ In addition, regional governments can assign some regional tax revenues to municipalities.

Because we focus on the degree of decentralization within regions, we exclude the "federal cities" of Moscow and St. Petersburg, as these cities do not have conventional municipalities and are exempt from some of the rules governing fiscal relationships between regions and their constituent municipalities. We also exclude Moscow oblast because a large part of it was ceded to the city of Moscow in 2012, making the data for 2005-2011 not comparable to the 2012-2013 numbers. We exclude two other regions - Ingushetia and Chechnya - due to their highly unreliable and extremely volatile budgetary and economic data. Finally, we aggregate most autonomous districts (okrugs) with the larger regions, which they joined during 2005-2007, and we exclude the Chukotka okrug. These okrugs are sparsely populated, very small entities relative to other regions. The only exceptions are the okrugs contained within Tyumen' and Arkhangelsk provinces. ${ }^{9}$ The fiscal relationship between these okrugs and the provinces in which they are located is rather atypical and it makes sense to exclude both the okrugs and the two provinces. After all of the exclusions stated above, we end up with a panel dataset containing observations on 72 regions for nine years, that is, 648 observations.

In calculating the expenditure decentralization measure, we remove the socalled subventions. These are transfers from the upper level of government that have fairly strictly prescribed uses. ${ }^{10}$ In essence, the lower level of government serves simply as an "expenditure agent" for the upper government level.

Specifically, we use the following formula to calculate a region's expenditure decentralization:

$$
\text { ExpDec }=\left(1-\frac{\text { RegExp }- \text { Trans }+ \text { MSubven }}{\text { ConsExp }- \text { RSubven }}\right) \times 100,
$$

where $\operatorname{RegExp}$ represents all expenditures of the regional government, Trans stands for transfers from the regional budget to the municipalities, MSubven represents the part of Trans that are "subventions" (i.e., the component of transfers to municipalities over which they have no control), ConsExp denotes overall expenditure of the consolidated (i.e., regional and municipal) budget, and RSubven are all subventions that appear on the revenue side of a consolidated regional budget.

\footnotetext{
${ }^{8}$ Since 2005 , about two thirds to almost $90 \%$ of the corporate income tax is assigned to regional budgets. Additionally, $70 \%$ of the personal income tax accrues to regional budgets, with the remainder going to municipal budgets. For a survey of Russia's fiscal federalism arrangements, see De Silva et al. (2009), Alexeev and Weber (2013), and Yushkov et al. (2017).

9 The degree of independence of these okrugs from their oblast differs. The two okrugs belonging to Tyumen' oblast are virtually fully fiscally independent, while the okrug in Arkhangelsk oblast has a fairly limited degree of autonomy.

${ }^{10}$ For example, one of the largest categories of subventions is unemployment compensation. This is in essence a federal expenditure, but the regional offices located in municipalities actually administer the payments. These arrangements leave very little discretion for the lower government level in terms of how to spend these transfers.
} 
We use the share of ethnic Russians and the homogeneity index for ethnic Russians as our ethnic diversity variables. ${ }^{11}$ These variables are available only from the 2010 census and thus do not vary over 2005-2013. We also experimented with using a conventional ethnolinguistic fractionalization index (calculated as $1-\sum_{i=1}^{n}\left(s_{i}\right)^{2}$, where $s_{i}$ is the share of each ethnic group) and a dummy variable for autonomous republics. The share of ethnic Russians has the strongest effect on the degree of fiscal decentralization. The regressions using other ethnic diversity measures are available upon request.

\subsection{United States}

We use data for 1997-2013, except for 2001 and 2003, for which state and local revenue and expenditure data are missing from the US Census website, leaving us with 15 data points for each of the 48 contiguous states in our benchmark regressions. Our dependent variable is the share of local (i.e., municipal) expenditures in the corresponding consolidated state amounts, expressed in percentage terms. We exclude expenditures of government-owned liquor stores, utilities, and social insurance trust funds. ${ }^{12}$ Our regressors are similar to those for Russia and listed at the beginning of the Data section. Most of the variables are either directly from US government sources or are calculated in a straightforward way. Data on the shares of urban population and the homogeneity index represent important exceptions. Urban shares are calculated based on the US Census data for 2000 and 2010 and assuming that the annual changes were the same for all years. The homogeneity index for non-Hispanic Whites is derived similarly to the homogeneity index for ethnic Russians (see footnote 7). We also tried the conventional index of ethnic fractionalization, but its effect on fiscal decentralization was somewhat weaker than the impact of the share of non-Hispanic Whites.

Tables 1 and 2 present the descriptions and sources for all of our variables. Tables 3 and 4 report the descriptive statistics. Note that both the range and the standard deviation of our dependent variables are fairly significant.

\section{Table 1}

Description of variables and sources for Russia.

\begin{tabular}{ll}
\hline Variable & Description \\
\hline $\begin{array}{l}\text { Gross regional product } \\
\text { (GRP) }\end{array}$ & $\begin{array}{l}\text { Real GRP in millions 2005 Russian rubles (RUB). Calculated based on 2005 } \\
\text { GRP in current prices and growth indices of physical output volumes for each } \\
\text { region. Source: Regiony Rossii for various years and authors' calculations. }\end{array}$ \\
$\begin{array}{l}\text { Expenditure } \\
\text { decentralization (\%) }\end{array}$ & $\begin{array}{l}\text { Calculated by authors based on formula (1). Source for the data in the formula: } \\
\text { Transfer dependence of } \\
\text { regional budget (\%) }\end{array}$ \\
$\begin{array}{l}\text { Patio of transfers, excluding subventions, and revenues of consolidated } \\
\text { regional budget. Source: www.roskazna.ru and authors calculations. }\end{array}$ \\
\end{tabular}

(continued on next page)

\footnotetext{
${ }^{11}$ Following W\&O, the homogeneity index for ethnic Russians is $(X-0.5)^{2}$, where $X$ represents the share of ethnic Russians in the region's overall population.

${ }^{12}$ We exclude expenditures of government-owned enterprises to make the data comparable across states and between the US and Russia.
} 
Table 1 (continued)

\begin{tabular}{|c|c|}
\hline Variable & Description \\
\hline Area & $\begin{array}{l}\text { Area of the region in thousand square kilometers. Source: Regiony Rossii for } \\
\text { various years. }\end{array}$ \\
\hline Gini coefficient & Source: http://www.gks.ru/dbscripts/cbsd/dbinet.cgi?pl=2340003 \\
\hline $\begin{array}{l}\text { Share of urban } \\
\text { population }(\%)\end{array}$ & $\begin{array}{l}\text { Shares of urban population in regional totals (\%). Source: Regiony Rossii for } \\
\text { various years. }\end{array}$ \\
\hline $\begin{array}{l}\text { Share of ethnic } \\
\text { Russians }\end{array}$ & $\begin{array}{l}\text { Share of ethnic Russians in regional population in 2010. Source: All-Russia } \\
\text { Census, available at http://www.gks.ru/free_doc/new_site/perepis2010/croc/ } \\
\text { perepis_itogi1612.htm }\end{array}$ \\
\hline $\begin{array}{l}\text { Index of homogeneity } \\
\text { for ethnic Russians }\end{array}$ & $\begin{array}{l}\text { Calculated as }(S-0.5)^{2} \text {, where } S \text { is the share of ethnic Russian population. } \\
\text { Source: Authors' calculations from All-Russia Census } 2010 \text {. }\end{array}$ \\
\hline $\begin{array}{l}\text { Per capita output of } \\
\text { mining }\end{array}$ & $\begin{array}{l}\text { Ratio of the mining component of gross regional product in } 2005 \mathrm{RR} \text { and } \\
\text { regional population. Source: Calculated by authors based on data from } \\
\text { Regiony Rossii for various years. }\end{array}$ \\
\hline $\begin{array}{l}\text { Share of social transfers } \\
\text { in personal income }\end{array}$ & $\begin{array}{l}\text { Ratio }(\%) \text { of public welfare payments and total personal income. Source: } \\
\text { Regiony Rossii for various years. }\end{array}$ \\
\hline $\begin{array}{l}\text { Carnegie overall } \\
\text { democracy index }\end{array}$ & $\begin{array}{l}\text { Composite democracy index from the Moscow Carnegie Center. The index } \\
\text { represents a sum of ratings of } 10 \text { categories of institutional quality. Each } \\
\text { category is rated from } 1 \text { to } 5 \text {, with higher ratings representing better institutions. } \\
\text { The components of the index are: transparency, fairness of elections, political } \\
\text { pluralism, independence of mass media, economic liberalization, civil society, } \\
\text { political structure, elites, corruption control, and local self-government. } \\
\text { Source: http://atlas.socpol.ru/indexes/index_democr.shtml }\end{array}$ \\
\hline
\end{tabular}

Table 2

Description of variables and sources for the US.

\begin{tabular}{|c|c|}
\hline Variable & Description \\
\hline $\begin{array}{l}\text { Gross state product } \\
(\text { GRP) }\end{array}$ & $\begin{array}{l}\text { Real GRP in millions } 2009 \text { chained USD. Source: Bureau of Economic } \\
\text { Analysis, Regional Product Division. }\end{array}$ \\
\hline $\begin{array}{l}\text { Consolidated state } \\
\text { expenditure }\end{array}$ & $\begin{array}{l}\text { Thousand USD. Source: U.S. Census Bureau, Annual Surveys of State and } \\
\text { Local Government Finances. }\end{array}$ \\
\hline $\begin{array}{l}\text { Federal transfers to state } \\
\text { and local governments }\end{array}$ & $\begin{array}{l}\text { Thousand USD. Source: U.S. Census Bureau, Annual Surveys of State and } \\
\text { Local Government Finances. }\end{array}$ \\
\hline Municipal expenditures & $\begin{array}{l}\text { Thousand USD. Source: U.S. Census Bureau, Annual Surveys of State and } \\
\text { Local Government Finances. }\end{array}$ \\
\hline Population & Number of state residents. Source: U.S. Census Bureau, Population Division. \\
\hline Area & $\begin{array}{l}\text { Area of the state in square miles. Source: U.S. Census Bureau (https://www. } \\
\text { census.gov/prod/2010pubs/10smadb/atables.pdf) }\end{array}$ \\
\hline Gini coefficient & $\begin{array}{l}\text { Gini coefficients from Frank-Sommeiller-Price Series. Source: http://www. } \\
\text { shsu.edu/eco_mwf/inequality.html }\end{array}$ \\
\hline $\begin{array}{l}\text { Share of urban } \\
\text { population }\end{array}$ & $\begin{array}{l}\text { Shares of urban population in } 2000 \text { and } 2010 \text { are from the U.S. Census } \\
\text { Bureau, Population Division. For the other years, shares are estimated } \\
\text { assuming constant annual rate of change. }\end{array}$ \\
\hline $\begin{array}{l}\text { Share of White } \\
\text { population }\end{array}$ & $\begin{array}{l}\text { Share of non-Hispanic Whites. Source: Calculated by authors from Intercensal } \\
\text { Population Estimates; U.S. Census Bureau, Population Division. }\end{array}$ \\
\hline $\begin{array}{l}\text { Index of homogeneity } \\
\text { for non-Hispanic Whites }\end{array}$ & $\begin{array}{l}\text { Calculated as }(S-0.5)^{2} \text {, where } S \text { is the share of non-Hispanic White popu- } \\
\text { lation. Source: Authors' calculations from Intercensal Population Estimates; } \\
\text { U.S. Census Bureau, Population Division. }\end{array}$ \\
\hline
\end{tabular}


Table 2 (continued)

\begin{tabular}{ll}
\hline Variable & Description \\
\hline $\begin{array}{l}\text { Per capita output of } \\
\text { mining }\end{array}$ & $\begin{array}{l}\text { Ratio of the mining component of gross state product in chained 2009 USD } \\
\text { and population. Source: Calculated by authors based on data from Bureau } \\
\text { of Economic Analysis, Regional Product Division and population data (see } \\
\text { above) }\end{array}$ \\
$\begin{array}{l}\text { Share of social transfers } \\
\text { in personal income }\end{array}$ & $\begin{array}{l}\text { Rensus Bureau, Annual Surveys of State and Local Government Finances } \\
\text { and Bureau of Economic Analysis, Regional Income Division. }\end{array}$ \\
$\begin{array}{l}\text { Individualistic political } \\
\text { nature }\end{array}$ & $\begin{array}{l}\text { A dummy variable denoting whether the state has an individualistic political } \\
\text { culture as determined by Daniel Elazar, who defined political culture } \\
\text { as "the particular pattern of orientation to political action in which each } \\
\text { political system is embedded" (Elazar, 1966, p. 78). One characteristic of } \\
\text { this political culture is the emphasis on limiting community/government } \\
\text { intervention in private activities. Source: Elazar (1966). }\end{array}$ \\
\hline
\end{tabular}

Table 3

Descriptive statistics for Russia (2005-2013).

\begin{tabular}{lllll}
\hline Variable & Mean & $\begin{array}{l}\text { Standard } \\
\text { deviation }\end{array}$ & Minimum & Maximum \\
\hline Expenditure decentralization (\%) & 32.36 & 8.225 & 9.972 & 57.91 \\
Land area (thousand square km) & 197.99 & 461.7 & 7.8 & $3,083.5$ \\
Population (people) & $1,576,460$ & $1,119,358$ & 151,335 & $5,367,227$ \\
Urban population (\%) & 68.51 & 11.59 & 26 & 95.80 \\
Per-capita GRP (year 2005 RUB) & 104,912 & 52,132 & 33,018 & 413,276 \\
Per-capita mining (year 2005 RUB) & 12,442 & 36,164 & 0 & 376,193 \\
Social Transfers / Personal income (\%) & 19.05 & 4.790 & 9.700 & 32.10 \\
Transfers from Federal government & 28.57 & 17.60 & 2.619 & 80.92 \\
$\quad$ (\% regional revenue) & & & & \\
Gini coefficient & 0.385 & 0.0234 & 0.316 & 0.451 \\
Share of ethnic Russians (\%) & 78.52 & 24.00 & 3.597 & 97.27 \\
Homogeneity index for Russians & 0.138 & 0.070 & 0.000676 & 0.223 \\
Carnegie democracy index (2000-2004) & 28.85 & 6.03 & 17 & 45 \\
\hline
\end{tabular}

Note: All descriptive statistics except for time-invariant variables are based on 648 observations for 72 regions; the time-invariant variables are based on 72 observations.

\section{Table 4}

Descriptive statistics for United States (1997-2013, excluding 2001 and 2003).

\begin{tabular}{lllll}
\hline Variable & Mean & $\begin{array}{l}\text { Standard } \\
\text { deviation }\end{array}$ & Minimum & Maximum \\
\hline Expenditure decentralization (\%) & 50.44 & 7.790 & 31.21 & 67.44 \\
Land area (square miles) & 64,996 & 47,660 & 1,545 & 268,581 \\
Population (people) & $6,124,152$ & $6,565,148$ & 489,451 & $3.84 \mathrm{e}^{+7}$ \\
Urban population (\%) & 72.47 & 14.63 & 37.97 & 95.17 \\
Per-capita GRP (2009 US dollars) & 44,446 & 8,177 & 28,372 & 69,897 \\
Per-capita mining (2009 US dollars) & 1,193 & 2,812 & 0 & 23,474 \\
Social Transfers / Personal income (\%) & 3.332 & 0.951 & 1.033 & 6.590 \\
Transfers from Federal government & 0.296 & 0.0848 & 0.143 & 0.692 \\
$\quad$ (\% state revenue) & & & & \\
Gini coefficient & 0.595 & 0.0359 & 0.521 & 0.711 \\
Share of non-Hispanic Whites (\%) & 0.751 & 0.136 & 0.390 & 0.978 \\
Homogeneity index for non-Hispanic Whites & 0.0817 & 0.0624 & $1.96 \mathrm{e}^{-6}$ & 0.228 \\
Individualistic political nature & 0.313 & 0.468 & 0 & 1 \\
\hline
\end{tabular}

Note: All descriptive statistics except for time-invariant variables are based on 720 observations for 48 contiguous states; the time-invariant variables are based on 48 observations. 


\section{Econometric specifications}

We estimate the following regression using the expenditure decentralization measure as a dependent variable:

$$
D e c_{i t}=\beta_{0}+\sum_{i=1}^{n} \beta_{i} x_{i t}+\mu S_{i}+\gamma T_{t}+\varepsilon_{i t},
$$

where $D e c_{i t}$ is an indicator of fiscal decentralization within region $i$ in year $t$.

The regressors represented by $x_{i t}$ in (2) are variables described in the Data section and in Tables 1-4. We use between-effects (BE) and OLS fixed-effects (FE) specifications to estimate (2). ${ }^{13}$ In the OLS FE regressions, we include dummy variables for years $\left(T_{t}\right)$ and regions $\left(S_{i}\right)$, and we cluster errors by region.

We also add a lagged dependent variable to (2) and estimate it using a systemGMM specification. This approach accounts for serial correlation in the data and for potential endogeneities. ${ }^{14}$ In addition, it provides another way to separate short- and long-term effects. The lagged dependent variable on the right hand side of (2) picks up the effect of history on the current value of the dependent variable and implies that only the current values of the other regressors might exert (short-term) influence on the dependent variable. This is true with respect to time-varying variables, but not necessarily with respect to time invariant factors because the former variables are first-differenced by the system-GMM, while the latter are not. Therefore, including the lagged dependent variable does not affect the coefficients of time-invariant variables in the same way as the coefficients of time-varying variables. Time-invariant variables reflect mostly an "average" long-term impact. We note, however, that the system-GMM approach is not highly reliable when the cross-sectional dimension is not large, as is the case in our data. In particular, the proliferation of internal instruments relative to the number of groups (i.e., regions, in our case) may result in relatively large standard errors, potentially lowering the statistical significance of the estimates.

Finally, we also estimate fixed effects regressions with spatial lags. More specifically, we estimate a dynamic Spatial Durbin Model (SDM): ${ }^{15}$

$$
\begin{aligned}
D e c_{i t}=\beta_{0} & +\alpha D e c_{i, t-1}+\rho \sum_{j=1}^{n} w_{i j} \operatorname{Dec}_{j t}+\sum_{i=1}^{n} \beta_{i} x_{i t}+\sum_{k=1}^{K} \sum_{j=1}^{n} w_{i j} x_{j t k} \theta_{k}+ \\
& +\mu S_{i}+\gamma T_{t}+\varepsilon_{i t},
\end{aligned}
$$

where $w_{i j}$ denotes the inverse values of distances between the regions. Including spatial lags is important when working with regional-level data, because most regions of a federation are smaller than many countries. In addition, it is typically much easier for the factors of production and information to move across regional lines than it is to cross international borders. For these reasons, developments in neighboring regions could have profound effects on outcomes in a given region or province.

\footnotetext{
13 The Hausman test rejects random effects specification for expenditure regressions with $p$-values of slightly greater than 0.01 for the US and 0.05 for Russia.

14 See Roodman (2009) for a helpful description of the system-GMM estimation and specifically of Stata's user-written xtabond 2 procedure that we employed.

15 We use the xsmle procedure in Stata to estimate the SDM. See LeSage and Pace (2009) for a detailed description of spatial lag estimation.
} 
Below, we sometimes refer to OLS FE, system-GMM, and spatial lags regressions with fixed effects as either "FE-type regressions" or "regressions that account for state fixed effects."

\section{Estimation results and discussion}

\subsection{Estimates for Russia}

Table 5 shows the estimates of (2) and (3) for Russia. The only coefficients that are consistently statistically significant in the regressions that account for regional fixed effects (columns 2 through 4 of Table 5) are those of per capita mining output. ${ }^{16}$ Interestingly, even spatial lags of mining revenue appear to promote centralization. However, the economic effect of mining revenues on decentralization is not large. The point estimate of the direct effect of per-capita mining revenues (column 4 of Table 5) implies that a one standard deviation increase in per-capita mining revenues from its mean value would reduce the fiscal decentralization measure by slightly more than one percentage point, or about one eighth of its standard deviation.

The pro-centralization effect of mining is in line with the discussion in Section 2, as well as with the findings obtained for Russia's regions by F\&P based on the data for the late 1990s-2001. We note, however, that during the period examined by $\mathrm{F} \& \mathrm{P}$, the regions kept a much larger share of rents from oil and natural gas, and to a somewhat lesser extent, from minerals. ${ }^{17}$ Therefore, our finding is important because it shows that even smaller natural resource rents result in significantly lower expenditure decentralization in Russia's regions. ${ }^{18}$ The logarithm of population exhibits a positive and statistically significant ( $p$-value 0.047 ) effect in the system-GMM regression, but neither the OLS FE nor the spatial lags regressions confirm this result. However, if we use this point estimate, its numerical effect is quite large. a one standard deviation increase in a region's population size results in almost a one half standard deviation increase in the degree of expenditure decentralization.

Regressions that include regional fixed effects have the advantage of controlling for unobserved time-invariant factors, but may conceal the influence of constant or slowly changing variables. It is useful, therefore, to examine between-effects $(\mathrm{BE})$ regressions, but considering that they are more likely than fixed-effects regressions to suffer endogeneity problems, particularly due to omitted variables. In our BE regressions, the share of urban population and the share of ethnic Russians are positively associated with expenditure decentralization. As noted earlier, theoretically, the effect of urbanization is ambiguous and thus the positive coefficient obtained in our BE regressions does not contradict expectations.

\footnotetext{
$\overline{16}$ We obtain qualitatively similar results using the logarithm of the share of mining in GRP instead of the logarithm of per-capita mining output value.

17 Until 2003, regional budgets received $20 \%$ of oil and natural gas extraction tax. The regional share declined drastically in 2004-2005, becoming zero for natural gas in 2004 and for oil in 2010 (the regional share of the oil tax declined to $5 \%$ in 2005). The federal share of the extraction tax for other minerals increased from 25 in 2001 to $40 \%$ starting in 2002. Additionally, value-added tax revenues were centralized at the federal level in 2001.

18 We note, however, that F\&P analyzed only BE regressions. In our between-effects specification, the coefficient of mining is actually positive, albeit statistically insignificant.
} 
Table 5

Factors determining expenditure decentralization in Russia’s regions (2005-2013).

\begin{tabular}{|c|c|c|c|c|c|}
\hline Variables & $\begin{array}{l}\text { (1) } \\
\text { BE OLS }\end{array}$ & $\begin{array}{l}(2) \\
\text { FE OLS }\end{array}$ & $\begin{array}{l}(3) \\
\text { System- } \\
\text { GMM }\end{array}$ & $\begin{array}{l}(4) \\
\text { Spatial lags } \\
\text { (Main) }\end{array}$ & $\begin{array}{l}\text { (5) } \\
\text { Spatial lags } \\
(\mathrm{Wx})\end{array}$ \\
\hline Log of land area & $\begin{array}{l}-0.135 \\
(0.601)\end{array}$ & & $\begin{array}{l}1.097 \\
(1.359)\end{array}$ & & \\
\hline Log of population & $\begin{array}{c}0.584 \\
(1.182)\end{array}$ & $\begin{array}{c}19.126 \\
(20.575)\end{array}$ & $\begin{array}{l}7.420^{* *} \\
(3.728)\end{array}$ & $\begin{array}{c}21.863 \\
(18.537)\end{array}$ & $\begin{array}{l}-88.241 \\
(224.359)\end{array}$ \\
\hline Urban population (\%) & $\begin{array}{l}0.133 * * \\
(0.065)\end{array}$ & $\begin{array}{c}0.304 \\
(0.346)\end{array}$ & $\begin{array}{c}0.125 \\
(0.471)\end{array}$ & $\begin{array}{c}0.291 \\
(0.308)\end{array}$ & $\begin{array}{l}-1.105 \\
(2.852)\end{array}$ \\
\hline Log of PC GRP & $\begin{array}{l}1.940 \\
(2.823)\end{array}$ & $\begin{array}{c}2.150 \\
(4.859)\end{array}$ & $\begin{array}{c}6.923 \\
(6.639)\end{array}$ & $\begin{array}{c}3.809 \\
(4.930)\end{array}$ & $\begin{array}{l}139.934 * * \\
(59.551)\end{array}$ \\
\hline Log of PC mining & $\begin{array}{c}0.467 \\
(0.290)\end{array}$ & $\begin{array}{l}-0.839 * * * \\
(0.278)\end{array}$ & $\begin{array}{l}-1.493 * * * \\
(0.385)\end{array}$ & $\begin{array}{l}-0.824 * * * \\
(0.284)\end{array}$ & $\begin{array}{l}-4.940^{* *} \\
(2.343)\end{array}$ \\
\hline $\begin{array}{l}\text { Social Transfers / Revenue } \\
(\%)\end{array}$ & $\begin{array}{l}-0.335 \\
(0.268)\end{array}$ & $\begin{array}{c}0.076 \\
(0.249)\end{array}$ & $\begin{array}{c}0.038 \\
(0.571)\end{array}$ & $\begin{array}{c}0.199 \\
(0.253)\end{array}$ & $\begin{array}{c}4.804 \\
(3.194)\end{array}$ \\
\hline $\begin{array}{l}\text { Transfers from Federal } \\
\text { government }(\%)\end{array}$ & $\begin{array}{c}0.025 \\
(0.074)\end{array}$ & $\begin{array}{l}-0.037 \\
(0.055)\end{array}$ & $\begin{array}{l}-0.081 \\
(0.078)\end{array}$ & $\begin{array}{l}-0.073 \\
(0.052)\end{array}$ & $\begin{array}{c}-1.246^{*} \\
(0.736)\end{array}$ \\
\hline Gini coefficient & $\begin{array}{l}-35.107 \\
(37.175)\end{array}$ & $\begin{array}{l}-33.879 \\
(54.151)\end{array}$ & $\begin{array}{l}-28.899 \\
(91.379)\end{array}$ & $\begin{array}{l}-23.975 \\
(52.623)\end{array}$ & $\begin{array}{l}512.609 \\
(615.663)\end{array}$ \\
\hline Share of ethnic Russians & $\begin{array}{l}0.117 * * * \\
(0.039)\end{array}$ & & $\begin{array}{c}0.027 \\
(0.096)\end{array}$ & & \\
\hline $\begin{array}{l}\text { Homogeneity index for } \\
\text { Russians }\end{array}$ & $\begin{array}{c}-5.187 \\
(11.251)\end{array}$ & & $\begin{array}{l}-23.561 \\
(20.577)\end{array}$ & & \\
\hline $\begin{array}{l}\text { Carnegie Center democracy } \\
\text { index }\end{array}$ & $\begin{array}{c}0.115 \\
(0.109)\end{array}$ & & $\begin{array}{l}-0.267 \\
(0.420)\end{array}$ & & \\
\hline $\begin{array}{l}\text { Expenditure decentralization } \\
\quad(t-1)\end{array}$ & & & $\begin{array}{l}0.248^{* * *} \\
(0.096)\end{array}$ & & \\
\hline Rho $(\rho)$ & & & & $\begin{array}{l}-1.943 * * * \\
(0.345)\end{array}$ & \\
\hline Observations & 648 & 648 & 576 & 648 & \\
\hline$R$-squared & 0.615 & 0.486 & & 0.502 & \\
\hline Number of regions & 72 & 72 & 72 & 72 & \\
\hline Number of instruments & & & 29 & & \\
\hline $\operatorname{AR}(2) p$-value & & & 0.526 & & \\
\hline Hansen $\mathrm{J}$ stat ( $p$-value) & & & 0.363 & & \\
\hline
\end{tabular}

Notes: All FE, system-GMM, and spatial lags regressions include time fixed effects; Robust standard errors clustered by region are in parentheses; Significance levels: $* * * p<0.01, * * p<0.05, * p<0.1$.

In terms of economic significance, a one standard deviation increase in the urban share of the regional population is associated with close to 1.5 percentage points (or about a one fifth standard deviation) increase in fiscal decentralization measure. The economic effect of the share of ethnic Russians implied by the estimate in Table 5 is fairly large. A one standard deviation increase in this share leads to an almost three percentage points increase in expenditure decentralization.

The decentralization-promoting impact of the share of ethnic Russians is hard to explain. This share is strongly negatively correlated with a region's ethnic diversity index (correlation coefficient of -0.89 ) and positively correlated with the ethnic Russians homogeneity index (correlation coefficient of 0.69). Therefore, this finding contradicts the conventional theory that greater ethnic diversity should lead to more fiscal decentralization (e.g., Panizza 1999). One explanation might be that more ethnically diverse regions tend to be more fiscally centralized to facilitate control of the region by the regional and perhaps central governments. We note also that a somewhat similar relationship exists in the US 
with respect to the effect of the homogeneity index of non-Hispanic Whites in the US states, as we show in the next subsection. ${ }^{19}$

Finally, we note that incorporating spatial lags does not significantly change the coefficients of the various factors relative to the simple OLS FE specification.

\subsection{Estimates for the United States}

Tables 6 and 7 present the estimates for the US. The former table contains the estimates based on 48 contiguous states, while the latter uses the data for all 50 states. The main reason for excluding Alaska and Hawaii from the regressions in Table 6

Table 6

Factors determining expenditure decentralization in the US 48 contiguous states (1997-2013).

\begin{tabular}{|c|c|c|c|c|c|}
\hline Variables & $\begin{array}{l}\text { (1) } \\
\text { BE OLS }\end{array}$ & $\begin{array}{l}(2) \\
\text { FE OLS }\end{array}$ & $\begin{array}{l}\text { (3) } \\
\text { System- } \\
\text { GMM }\end{array}$ & $\begin{array}{l}(4) \\
\text { Spatial lags } \\
\text { (Main) }\end{array}$ & $\begin{array}{l}(5) \\
\text { Spatial lags } \\
(\mathrm{Wx})\end{array}$ \\
\hline Log of land area & $\begin{array}{l}4.618 * * * \\
(0.970)\end{array}$ & & $\begin{array}{l}1.856^{* *} \\
(0.803)\end{array}$ & & \\
\hline Log of population & $\begin{array}{c}1.608 \\
(1.083)\end{array}$ & $\begin{array}{c}1.205 \\
(5.033)\end{array}$ & $\begin{array}{l}1.345^{* *} \\
(0.667)\end{array}$ & $\begin{array}{r}8.135^{*} \\
(4.242)\end{array}$ & $\begin{array}{c}28.703 \\
(60.823)\end{array}$ \\
\hline Urban population (\%) & $\begin{array}{l}-0.024 \\
(0.085)\end{array}$ & $\begin{array}{l}-0.019 \\
(0.138)\end{array}$ & $\begin{array}{l}-0.006 \\
(0.056)\end{array}$ & $\begin{array}{l}-0.036 \\
(0.141)\end{array}$ & $\begin{array}{c}-1.624 \\
(1.741)\end{array}$ \\
\hline Log of PC GSP & $\begin{array}{l}1.617 \\
(6.279)\end{array}$ & $\begin{array}{l}2.939 \\
(2.375)\end{array}$ & $\begin{array}{l}-3.210 \\
(4.642)\end{array}$ & $\begin{array}{l}4.887 * * \\
(2.122)\end{array}$ & $\begin{array}{l}73.788 * * \\
(28.890)\end{array}$ \\
\hline Log of PC mining & $\begin{array}{c}-0.436 \\
(0.588)\end{array}$ & $\begin{array}{l}-0.681^{* *} \\
(0.298)\end{array}$ & $\begin{array}{c}-0.287 \\
(0.400)\end{array}$ & $\begin{array}{l}-0.734 * * * \\
(0.252)\end{array}$ & $\begin{array}{c}-2.285 \\
(2.593)\end{array}$ \\
\hline $\begin{array}{l}\text { Social Transfers / Revenue } \\
(\%)\end{array}$ & $\begin{array}{c}-1.391 \\
(1.290)\end{array}$ & $\begin{array}{l}-1.650 * * * \\
(0.310)\end{array}$ & $\begin{array}{l}-2.053^{* * *} \\
(0.748)\end{array}$ & $\begin{array}{l}-1.904 * * * \\
(0.267)\end{array}$ & $\begin{array}{l}-4.043 \\
(2.891)\end{array}$ \\
\hline $\begin{array}{l}\text { Transfers from Federal } \\
\text { government }(\%)\end{array}$ & $\begin{array}{l}-25.450 \\
(17.997)\end{array}$ & $\begin{array}{l}-9.655^{* *} \\
(3.707)\end{array}$ & $\begin{array}{r}-10.422 \\
(6.906)\end{array}$ & $\begin{array}{c}-6.288^{*} \\
(3.624)\end{array}$ & $\begin{array}{c}40.391 \\
(33.156)\end{array}$ \\
\hline Gini coefficient & $\begin{array}{c}35.523 \\
(27.441)\end{array}$ & $\begin{array}{l}-7.722 * * \\
(3.281)\end{array}$ & $\begin{array}{l}0.697 \\
(6.154)\end{array}$ & $\begin{array}{l}-7.804 * * \\
(3.392)\end{array}$ & $\begin{array}{c}-67.097^{*} \\
(34.353)\end{array}$ \\
\hline $\begin{array}{l}\text { Share of non-Hispanic } \\
\text { Whites }\end{array}$ & $\begin{array}{c}11.286 \\
(17.547)\end{array}$ & $\begin{array}{c}4.420 \\
(12.449)\end{array}$ & $\begin{array}{l}-0.105 \\
(9.732)\end{array}$ & $\begin{array}{l}7.600 \\
(9.489)\end{array}$ & $\begin{array}{c}162.534 \\
(126.366)\end{array}$ \\
\hline $\begin{array}{r}\text { Homogeneity index for } \\
\text { non-Hispanic Whites }\end{array}$ & $\begin{array}{l}-36.007 \\
(41.045)\end{array}$ & $\begin{array}{c}8.875 \\
(16.057)\end{array}$ & $\begin{array}{c}2.040 \\
(20.100)\end{array}$ & $\begin{array}{l}28.593 * * * \\
(10.535)\end{array}$ & $\begin{array}{c}41.815 \\
(174.299)\end{array}$ \\
\hline $\begin{array}{l}\text { Individualistic political } \\
\text { nature }\end{array}$ & $\begin{array}{c}2.897 \\
(1.910)\end{array}$ & & $\begin{array}{c}1.391 \\
(1.049)\end{array}$ & & \\
\hline $\begin{array}{l}\text { Expenditure decentralization } \\
\quad(t-1)\end{array}$ & & & $\begin{array}{l}0.575^{* * *} \\
(0.092)\end{array}$ & & \\
\hline Rho $(\rho)$ & & & & $\begin{array}{l}-1.368 * * * \\
(0.357)\end{array}$ & \\
\hline Observations & 720 & 720 & 672 & 720 & \\
\hline$R$-squared & 0.748 & 0.711 & & 0.746 & \\
\hline Number of States & 48 & 48 & 48 & 48 & \\
\hline Number of instruments & & & 36 & & \\
\hline $\operatorname{AR}(2)$ ( $p$-value) & & & 0.181 & & \\
\hline Hansen $\mathrm{J}$ ( $p$-value) & & & 0.302 & & \\
\hline
\end{tabular}

Notes: All FE, system-GMM, and spatial lags regressions include time fixed effects; Robust standard errors clustered by state are in parentheses; Significance levels: $* * * p<0.01, * * p<0.05, * p<0.1$.

\footnotetext{
${ }^{19}$ Ethnolinguistic diversity also appears to promote fiscal centralization in country-level regressions (see, for example, Arzaghi and Henderson, 2005). The explanation relates to the desire of the central government to prevent secessionist tendencies of ethnically different regions. This explanation does not seem to be relevant for the case of intraregional ethnic diversity.
} 
Table 7

Factors determining expenditure decentralization in the US 50 states (1997-2013).

\begin{tabular}{|c|c|c|c|}
\hline Variables & $\begin{array}{l}\text { (1) } \\
\text { BE OLS }\end{array}$ & $\begin{array}{l}\text { (2) } \\
\text { FE OLS }\end{array}$ & $\begin{array}{l}\text { (3) } \\
\text { System-GMM }\end{array}$ \\
\hline Log of land area & $\begin{array}{l}3.778 * * * \\
(0.968)\end{array}$ & & $\begin{array}{l}2.745^{* *} \\
(1.121)\end{array}$ \\
\hline Log of population & $\begin{array}{l}3.334 * * * \\
(1.108)\end{array}$ & $\begin{array}{c}3.503 \\
(4.883)\end{array}$ & $\begin{array}{c}0.617 \\
(1.075)\end{array}$ \\
\hline Urban population $(\%)$ & $\begin{array}{c}0.006 \\
(0.096)\end{array}$ & $\begin{array}{c}-0.067 \\
(0.128)\end{array}$ & $\begin{array}{c}0.014 \\
(0.065)\end{array}$ \\
\hline Log of PC GSP & $\begin{array}{l}-0.930 \\
(7.143)\end{array}$ & $\begin{array}{c}4.015 \\
(2.560)\end{array}$ & $\begin{array}{l}-3.304 \\
(4.162)\end{array}$ \\
\hline Log of PC mining & $\begin{array}{l}-2.345 \\
(1.615)\end{array}$ & $\begin{array}{l}-2.122 * * \\
(0.877)\end{array}$ & $\begin{array}{c}-2.177^{*} \\
(1.262)\end{array}$ \\
\hline Social Transfers / Revenue (\%) & $\begin{array}{l}-3.232 * * * \\
(1.105)\end{array}$ & $\begin{array}{l}-1.472 * * * \\
(0.340)\end{array}$ & $\begin{array}{l}-1.891 * * * \\
(0.630)\end{array}$ \\
\hline Transfers from Federal government (\%) & $\begin{array}{c}4.329 \\
(18.687)\end{array}$ & $\begin{array}{c}-12.456 \text { *** } \\
(3.759)\end{array}$ & $\begin{array}{c}-12.957 * * \\
(5.804)\end{array}$ \\
\hline Gini coefficient & $\begin{array}{c}27.062 \\
(30.992)\end{array}$ & $\begin{array}{l}-8.550 * * \\
(3.357)\end{array}$ & $\begin{array}{l}-3.577 \\
(7.657)\end{array}$ \\
\hline Share of non-Hispanic Whites & $\begin{array}{l}29.484 * * * \\
(10.440)\end{array}$ & $\begin{array}{c}6.482 \\
(11.587)\end{array}$ & $\begin{array}{l}4.021 \\
(6.972)\end{array}$ \\
\hline Homogeneity index for non-Hispanic Whites & $\begin{array}{c}-53.038^{*} \\
(26.752)\end{array}$ & $\begin{array}{c}11.176 \\
(14.435)\end{array}$ & $\begin{array}{c}-3.368 \\
(11.819)\end{array}$ \\
\hline Individualistic political nature & $\begin{array}{c}3.486 \\
(2.195)\end{array}$ & & $\begin{array}{c}2.390^{* *} \\
(1.118)\end{array}$ \\
\hline Expenditure decentralization $(t-1)$ & & & $\begin{array}{l}0.578^{* * *} \\
(0.090)\end{array}$ \\
\hline Constant & $\begin{array}{l}-55.831 \\
(83.368)\end{array}$ & $\begin{array}{l}-54.642 \\
(74.549)\end{array}$ & $\begin{array}{c}26.529 \\
(46.558)\end{array}$ \\
\hline Observations & 750 & 750 & 700 \\
\hline$R$-squared & 0.744 & 0.694 & \\
\hline Number of States & 50 & 50 & 50 \\
\hline Number of instruments & & & 36 \\
\hline $\operatorname{AR}(2)(p$-value $)$ & & & 0.172 \\
\hline Hansen $\mathrm{J}$ ( $p$-value) & & & 0.256 \\
\hline
\end{tabular}

Notes: All FE and system-GMM regressions include time fixed effects; Robust standard errors clustered by state are in parentheses; Significance levels: $* * * p<0.01,{ }^{* *} p<0.05, * p<0.1$.

is that spatial lag regressions make sense only for the contiguous states. In addition, the non-contiguous states are rather unusual. Hawaii is located on several islands and has the smallest non-Hispanic Whites share of the population in the US, and Alaska has by far the largest land mass of all states and one of the smallest populations, implying drastically lower population density than in any other state.

Unlike in the case of Russia, the coefficients on the size of the state (land area and population) are positive, with land area being statistically significant in both the BE and system-GMM equations, while population size is significant in the system-GMM and spatial lag regressions for the 48 contiguous states and for the BE regressions for the 50 states. These results imply that larger states tend to be more decentralized, which is fully consistent with conventional theory. The numerical value of the effect of land area depends on whether we use the system-GMM or BE point estimate. Using the former, a one standard deviation increase in land area results only in about a one-eighths standard deviation increase in the decentralization measure. The corresponding increase in decen- 
tralization according to the BE specification is one third of its standard deviation. The numerical effect of population is quite small.

No other variable except for land area is statistically significant in the BE regressions in Table 6. In the BE regressions for all 50 states, however, the coefficient of the share of social transfers in revenue is negative and strongly statistically significant, while the share of non-Hispanic Whites has a positive coefficient significant at the $1 \%$ level and the homogeneity index is negative and significant at $10 \%$ level. Although the results for all 50 states are consistent with the findings from the FE-type regressions, to the extent they differ from those for 48 contiguous states, they should be interpreted with caution since they are apparently driven by Alaska and Hawaii - two rather unusual states, as argued above.

In the FE-type regressions, the share of social transfers in state revenues is negative and highly statistically significant in all specifications. The effect of social transfers is substantial numerically. A one standard deviation increase in this variable results in about a quarter standard deviation decrease in the decentralization measure. Per-capita mining output, dependence on federal transfers, and income inequality measured by the Gini coefficient are negative and statistically significant at least at the 5\% level in the OLS FE and spatial lag regressions, but not statistically significant in the system-GMM specification for the 48 contiguous states. We view the OLS FE and spatial lag regressions as more reliable due to the relatively small cross-sectional dimension of the US data (particularly for the 48 states), which reduces the performance of system-GMM approach. The signs of these coefficients are fully consistent with theoretical predictions discussed in Section 2. The numerical effect of these variables, however, is not large. A one standard deviation increase in each results in less than a one-tenth standard deviation decrease in decentralization.

Per-capita GSP is positive and significant in the spatial lag regression but not in the other regressions. Since the spatial lag specification is more appropriate than OLS FE for regions within a single country, this result confirms the view of fiscal decentralization as a normal good. The system-GMM regression for the 50 states suggests that the individualistic political nature of the state tends to be associated with greater fiscal decentralization. Although this result is consistent with our priors, we should view it with caution since it is not confirmed by the regression for the 48 states, and the corresponding coefficients in the BE regressions for the 48 and 50 states have $p$-values of only 0.138 and 0.12 , respectively. Finally, the homogeneity index for non-Hispanic Whites is also positive and significant at the $1 \%$ level in the spatial lag regression. As in the case of the share of ethnic Russians, the decentralization-promoting role of the homogeneity index of non-Hispanic Whites is somewhat surprising. Similar to the Russian case, we conjecture that state governments in less racially homogeneous states prefer to exert greater fiscal control over their constituent municipalities.

\subsection{Discussion of main implications}

The main implications of the estimates presented in the two subsections above are that the factors determining fiscal decentralization in the US are largely, albeit not fully, consistent with the conventional theory and with W\&O's estimates, while the standard determinants of fiscal decentralization, with one notable ex- 
ception, do not appear to be at work in Russia's regions. Perhaps the most surprising result is that a region's size measured by either land area or population does not seem to have a meaningful impact on intraregional fiscal decentralization in Russia, although population size is statistically significant in one specification. This outcome is at odds with the straightforward theoretical considerations, as well as with F\&P's results that contained a statistically significant positive relationship between a region's size and decentralization. F\&P also found a negative and highly statistically significant effect of regional transfer dependence on fiscal decentralization, while the respective coefficient in our BE regression for Russia is statistically insignificant. Moreover, although in most of F\&P's BE specifications both per-capita GRP and the degree of urbanization had negative statistically significant coefficients, the respective BE coefficients in our "Russian" regressions are positive, and one is statistically significant. In fact, the only finding from the BE regressions based on our data that is comparable to F\&P's results is the fiscal decentralization-promoting effect of the share of ethnic Russians in a region. ${ }^{20}$ At the very least, the comparisons between F\&P's and our findings imply that reforms of the intergovernmental fiscal relationships and other institutional developments in Russia since the early 2000s significantly altered the factors influencing intraregional fiscal decentralization.

The almost complete absence of the conventional determinants of fiscal decentralization in Russia contrasts with the situation in the US, where the determinants of fiscal decentralization are largely consistent with conventional theory, particularly in the regressions that account for state fixed effects. We conjecture that the differences between Russia and the US in this regard can be explained by the relatively small size of most Russian regions (particularly in terms of population, but also in terms of inhabited land areas), ${ }^{21}$ lower cross-regional population mobility in Russia than in the US, weaker intraregional democratic institutions, and greater centralization in the Russian political system in general. It is likely that all of these characteristics contribute to the differences between the factors affecting decentralization in these countries. Below, we present a brief discussion of how each of Russia's regional characteristics might have affected regional authorities' responsiveness to the factors that typically influence the degree of fiscal decentralization.

Regional size. Although the mean area of Russia's regions in our sample is greater than the mean area for the 48 contiguous US states, most of that difference is due to just two large sparsely populated regions (Yakutia and Krasnoyarskii krai). Without those two regions, the mean area of the remaining Russian regions is considerably smaller than that of US states. In addition, the median area of Russia's regions is less than half of the median for the US states. If intraregional fiscal decentralization begins to make economic and political sense starting only from a certain size threshold, smaller regions might not reach that threshold, and thus their degree of decentralization would not have a meaningful relationship to their size. This consideration is unlikely to play a major role, however, because

\footnotetext{
${ }^{20} \mathrm{~F} \& \mathrm{P}$ used the index of ethno-linguistic fractionalization (ELF) and obtained a negative relationship of this index with fiscal decentralization. We obtained similar results for ELF, but a somewhat stronger statistical relationship between the share of ethnic Russians and decentralization.

${ }^{21}$ Some of Russia's regions have very large areas, but the populated parts of these large regions are typically very small, such as Krasnoyarsk province or Yakutia, for example.
} 
regional size did matter in F\&P's regressions, although its statistical significance was only marginal.

Population mobility and weak democratic institutions. Low population mobility across regional boundaries and underdeveloped democratic institutions reduce regional authorities' accountability to their constituencies because neither conventional voting nor voting by feet $\grave{a}$ la Tiebout (1956) is effective. ${ }^{22}$ Consequently, citizens cannot push regional governments to accommodate their desires for decentralization when, for example, personal incomes rise or the region's population increases. When government accountability is low, even factors related to the costs of providing public goods may not be relevant. For example, although spatially large regions are usually cheaper to administer in a decentralized manner, the regional center may lack incentives to lower administrative costs at the expense of reducing its control over the region. However, the population mobility explanation is suspect because similar to regional size, this factor has not changed significantly relative to the period analyzed by F\&P, while the influence of several decentralization factors that were found to be important in 19962001 are no longer discernable. In contrast, the degree of intraregional democracy has declined since the early 2000s (e.g., as mentioned earlier, the abolition of regional governor elections), making this explanation more likely to be valid.

Federal political and fiscal centralization. Another obvious political change since the early $2000 \mathrm{~s}$ is a significant increase in political and fiscal centralization at the federal level, that is, the large increase in the power of the federal government relative to that of regional authorities during the 2000s. As we described in the Introduction, this centralization has been evidenced, for example, in a substantial decrease in the share of regional revenues and expenditures in the consolidated budget totals. Both political and fiscal centralization make the regional governments beholden to the federal center, and thus the degree of intra-regional decentralization becomes largely irrelevant to their actions and incentives. In addition, a centralized political system creates uniform fiscal rules for all regions, leaving regional governments only a limited degree of discretion.

As noted earlier, the US determinants of intrastate decentralization are generally consistent with conventional theory. However, our regressions produced several notable differences with the earlier work by W\&O. Specifically, although the size of the state has a pro-decentralization effect, both in our regressions and in $\mathrm{W} \& \mathrm{O}$, we obtain highly statistically and economically significant estimates for land area, while W\&O do not (except in univariate regressions). Additionally, our coefficients on the degree of urbanization are statistically insignificant, while according to $\mathrm{W} \& \mathrm{O}$, urbanization has a strong decentralizing effect. Perhaps the starkest difference, however, is the highly statistically significant positive association between per-capita GSP and fiscal decentralization in

\footnotetext{
${ }^{22}$ General mobility in Russia is approximately $1.5-3 \%$ (1.9-4 million people per year of a population of somewhat more than 140 million, according to Rosstat, available at http://www.gks.ru/wps/wcm/connect/ rosstat_main/rosstat/ru/statistics/population/demography/\#) compared to about $11 \%$ in the US (calculated based on US Census Bureau data available at https://www.census.gov/data/tables/2016/demo/geographic-mobility/ cps-2016.html). Interregional migration in Russia is also less than interstate migration in the US (less than $1 \%$ in most years in our sample vs. $1.5 \%$ ). Although we do not have data for specific regions in Russia, we conjecture that interregional migration there would be considerably smaller if we exclude Moscow, Moscow province, and St. Petersburg, which we excluded from our sample.
} 
our spatial lag regressions and the strong opposite effect of per-capita income obtained by W\&O. Our estimates of the effect of the homogeneity index for non-Hispanic Whites is similar to W\&O's, although they also find that a higher percentage of non-Hispanic Whites is associated with greater decentralization, while in our regressions, the respective coefficient is insignificant. Interestingly, $\mathrm{W} \& \mathrm{O}$ conjecture (but do not estimate) that income inequality within a state would promote fiscal decentralization, while we find the opposite effect. We also estimate some other important effects that W\&O do not. Namely, we find that the share of mining in GSP, the share of social welfare transfers in state revenue, and the state dependence on federal transfers all reduce fiscal decentralization, while the individualistic political nature of the state appears to have a weak decentralizing effect. Finally, unlike W\&O, we do not find a significant difference between Southern and other states in terms of fiscal decentralization. ${ }^{23}$ These differences between our estimates and those of $\mathrm{W} \& \mathrm{O}$ are unlikely a result of some institutional changes in the states. They are more likely to be the outcome of different estimation techniques and data availability. As we stated earlier, the random-effects specification used by $\mathrm{W} \& \mathrm{O}$ is rejected by Hausman test for our data, and it presumably would have been rejected for W\&O's data too. Therefore, we would argue that our econometric approach is more appropriate than W\&O's, and that our results are more reliable.

\section{Conclusion}

We estimate and compare the determinants of fiscal decentralization in Russia's regions and US states using panel data and several econometric specifications. The pattern of fiscal decentralization in the US largely conforms to existing theories, although our results are different in some important respects from the earlier estimates by Wallis and Oates (1988). We also find that unlike in the US, almost no regional characteristics have consistent effects on the degree of intraregional fiscal decentralization in Russia. Moreover, our estimates for Russia are also at odds with the empirical work by Freinkman and Plekhanov (2009) based on the earlier data. We conjecture that this finding is due mostly to the weakened democratic institutions in Russia's regions and to the increased political and economic centralization of the country overall.

\section{References}

Ahmad, E., \& Brosio, G. (2015). Handbook of multilevel finance. Northampton, MA: Edward Elgar. Alexeev, M., \& Weber, S. (2013). Russian fiscal federalism: Impact of political and fiscal (de)centralization. In M. Alexeev, \& S. Weber (Eds.), The Oxford handbook of the Russian economy (pp. 643-660). New York: Oxford University Press.

Arzaghi, M., \& Henderson, J. V. (2005). Why countries are fiscally decentralizing. Journal of Public Economics, 89 (7), 1157-1189.

\footnotetext{
23 The regression estimates that include Southern states are not reported, but are available upon request. Including a dummy variable for the Southern states in the BE regressions produces a statistically insignificant coefficient and does not qualitatively affect the other coefficient estimates. Including this dummy variable in the system-GMM regression either results in a failed Hansen $\mathrm{J}$ test of instrument validity or produces too many instruments, depending on the options we use in the regression.
} 
Canavire-Bacarreza, G., Martinez-Vazquez, J., \& Yedgenov, B. (2016). Reexamining the determinants of fiscal decentralization: what is the role of geography? Journal of Economic Geography, lbw032, https://doi.org/10.1093/jeg/lbw032.

De Silva, M. O., Kurlyandskaya, G., Andreeva, E., \& Golovanova, N. (2009). Intergovernmental reforms in the Russian Federation: One step forward, two steps back? Washington, DC: World Bank.

Gabaix, X. (1999). Zipf's law for cities: An explanation. Quarterly Journal of Economics, 114 (3), $739-767$.

Elazar, D. J. (1966). American federalism: A view from the states. New York: Thomas Y. Crowell Company.

Freinkman, L., \& Plekhanov, A. (2009). Fiscal decentralization in rentier regions: Evidence from Russia. World Development, 37 (2), 503-512.

Inman, R. P. (2008). The flypaper effect. NBER Working Paper, No. 14579

Jametti, M., \& Joanis, M. (2016). Electoral competition as a determinant of fiscal decentralisation. Fiscal Studies, 37 (2), 285-300.

LeSage, J., \& Pace, R. K. (2009). Introduction to spatial econometrics. Boca Raton: Chapman \& Hall/CRC.

Letelier, L. S. (2005). Explaining fiscal decentralization. Public Finance Review, 33 (2), 155-183.

Martinez-Vazquez, J., Lago-Penas, S., \& Sacchi, A. (2016). The impact of fiscal decentralization: A survey. Journal of Economic Surveys, 31 (4), 1095-1129.

OECD (2017). Fiscal decentralization database. Online at http://www.oecd.org/tax/federalism/ fiscal-decentralisation-database.htm

Panizza, U. (1999). On the determinants of fiscal centralization: Theory and evidence. Journal of Public Economics 74 (1), 97-139.

Prud'homme, R. (1995). The dangers of decentralization. World Bank Research Observer, 10 (2), 201-220.

Roodman, D. (2009). How to do xtabond2: An introduction to difference and system GMM in Stata. Stata Journal, 9 (1), 86-136.

Tiebout, Ch. M. (1956). A pure theory of local expenditures. Journal of Political Economy, 64 (5), $416-424$.

Wallis, J., \& Oates, W. (1988). Decentralization in the public sector: An empirical study of state and local government. In: H. Rosen (Ed.), Fiscal federalism: Quantitative studies (pp. 5-32). Chicago: University of Chicago Press.

World Bank (2014). Governance and public sector management: Fiscal decentralization indicators. Online at http://web.worldbank.org/WBSITE/EXTERNAL/TOPICS/EXTPUBL ICSECTORANDGOVERNANCE/0,,contentMDK:23112839 pagePK:148956 piPK:2166 18 theSitePK:286305,00.html

Yushkov, A., Savulkin. L., \& Oding, N. (2017). Intergovernmental relations in Russia: Still a pendulum? Public Administration Issues, Special Issue (electronic edition), 38-59; doi: 10.17323/1999-5431-2017-0-5-38-59. 